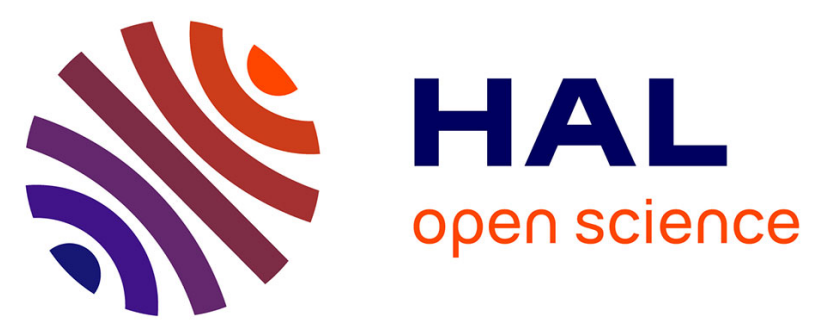

\title{
PREDATION OF MUDFLAT MEIO-MACROFAUNAL METAZOANS BY A CALCAREOUS FORAMINIFER, AMMONIA TEPIDA (CUSHMAN, 1926)
}

Christine Dupuy, Linda Rossignol, Emmanuelle Geslin, Pierre-Yves Pascal

\section{- To cite this version:}

Christine Dupuy, Linda Rossignol, Emmanuelle Geslin, Pierre-Yves Pascal. PREDATION OF MUDFLAT MEIO-MACROFAUNAL METAZOANS BY A CALCAREOUS FORAMINIFER, AMMONIA TEPIDA (CUSHMAN, 1926). Journal of Foraminiferal Research, 2010. hal-01248040

\section{HAL Id: hal-01248040 https://hal.science/hal-01248040}

Submitted on 26 Dec 2016

HAL is a multi-disciplinary open access archive for the deposit and dissemination of scientific research documents, whether they are published or not. The documents may come from teaching and research institutions in France or abroad, or from public or private research centers.
L'archive ouverte pluridisciplinaire $\mathbf{H A L}$, est destinée au dépôt et à la diffusion de documents scientifiques de niveau recherche, publiés ou non, émanant des établissements d'enseignement et de recherche français ou étrangers, des laboratoires publics ou privés. 
LRH: PREDATION ON METAZOANS BY AMMONIA TEPIDA

PREDATION OF MUDFLAT MEIO-MACROFAUNAL METAZOANS BY A CALCAREOUS FORAMINIFER, AMMONIA TEPIDA (CUSHMAN, 1926)

CHRISTINE DUPUY ${ }^{1,5}$, LINDA RosSIGNOL ${ }^{2}$, EMMANUELLE GESLIN ${ }^{3}$ AND PIERRE-YVES PASCAL ${ }^{4}$

${ }^{1}$ Université de La Rochelle, Institut du Littoral et de l'Environnement, UMR 6250, 2, rue Olympe de Gouges, 17000 La Rochelle cedex, France.

${ }^{2}$ Université Bordeaux 1, Laboratoire EPOC, UMR 5805, Avenue des Facultés, 33405 Talence cedex, France.

${ }^{3}$ BIAF (Laboratoire des Bio-Indicateurs Actuels et Fossiles), UPRES EA 2644, Université d'Angers, 2 bd Lavoisier, 49045 Angers cedex, and LEBIM, Yeu Island, France.

${ }^{4}$ Louisiana State University, Department of Biological Sciences, Life Sciences Building, Baton Rouge, LA 70803, USA.

${ }^{5}$ Correspondence author: E-mail: cdupuy@univ-lr.fr 
Benthic foraminifera are heterotrophic protists that utilize different trophic mechanisms and nutritional resources. They exhibit a wide range of trophic behaviours: selective (grazing) and indiscriminate herbivory, symbiosis, carnivory, parasitism, uptake of dissolved organic matter, passive suspension feeding and, most commonly, deposit feeding. The benthic foraminifera Ammonia tepida, previously known as an herbivore, fed as a carnivore in laboratory experiments where mobile metazoans were provided. We observed predation on the three types of metazoans provided: nematodes, copepods, and a larval gastropod. This foraminifera used its pseudopodial network to entrap the invertebrates, which were then stripped of their soft internal tissues within 24 hours. Our experiments are the first to demonstrate that Ammonia tepida, despite its limited motility, is able to utilize larger mobile animals as a food source. The great abundance of small metazoans in most marine environments suggests that they are a food source for foraminifera. Further study of foraminiferal feeding strategies will enhance our understanding of their role in marine communities.

Keywords: Mudflat, foraminifera, Ammonia tepida, grazing, nematodes, benthic copepods, Hydrobia ulvae 


\section{INTRODUCTION}

Foraminifera are heterotrophic protists present in both pelagic and benthic marine environments. Benthic foraminifera inhabit all water depths and populate a variety of microhabitats on and in the substrate (Murray, 1991; Ellison, 1984; Chandler, 1989; Moodley and others, 1998; 2000; 2002; 2005; Murray and Alve, 2000). They utilize a diversity of trophic mechanisms and nutritional resources (Goldstein, 1999), and probably play an important role in food webs that influences the structure of the benthic community (Altenbach, 1992; Linke and others, 1995; Moodley and others; 2000; Fontanier and others, 2002; Nomaki and others, 2008; Suhr and others, 2008).

Trophic behaviors exhibited by foraminifera include selective (grazing) and indiscriminate herbivory (Jeeps, 1942; Sliter, 1965; Jones and Charnock, 1985; Lee and others, 1991; Moodley and others 2002; Witte and others, 2003; Nomaki and others, 2008), symbiosis (Lee and Anderson, 1991), parasitism (Cedhagen, 1994), uptake of dissolved organic matter (DeLaca and others, 1981; Lipps, 1983), passive suspension feeding (Lipps, 1983; Cedhagen, 1988; Lutze and Altenbach, 1988; Lutze and Thiel, 1989), and deposit feeding (Lipps 1983; Jones and Charnock, 1985). The majority of foraminiferal species are assumed to be omnivorous, feeding on organic detritus, bacteria, and algae (Lee, 1980; Lipps, 1983). Some foraminifera are known to feed on metazoans (Buchanan and Hedley, 1960; Bowser and others, 1986, 1992; Goldstein, 1999; Suhr and others, 2008), but most of them are not exclusively carnivorous and utilize carnivory in addition to at least one other trophic mechanism (Goldstein, 1999). Carnivory by planktonic foraminifera is well documented (e.g. Boltovskoy and Wright, 1976, Bé and others, 1977), but little is known about this behavior among benthic foraminifera (see review in Goldstein, 1999). The position of foraminifera in food webs remains conjectural despite direct observations on the diets of some species (Murray, 1963; Anderson and Lee, 1991; Lee and others, 1991; Bernhard and Bowser, 1992; Goldstein, 1999; Heinz and others, 2005; Pascal and others, 2008a).

Foraminifera typically use their pseudopodia to gather and ingest food (Bowser and others, 1992). Planktonic foraminifera are known to prey upon copepods and other crustaceans (Anderson and Bé, 1976; Bé and others, 1977; Caron and Bé, 1984; Snider and others, 1984; Hemleben and others, 
1988). Some larger benthic foraminifera also feed on metazoans. For example, Peneroplis pertusus (Forskål) feeds on copepods by ingesting the internal soft parts after which it discards the empty carapace (Winter, 1907 cited by Goldstein, 1999). The large agglutinated foraminifera Astrorhiza limnicola (Sandahl) feeds on crustaceans and echinoderms (Nyholm, 1956; Buchanan and Hedley, 1960); however, the same species has also been observed only as a suspension feeder (Cedhagen, 1988). Several authors (DeLaca, 1986; Bowser and others, 1992; Suhr and others, 2008) consider Astrammina rara (Rhumbler), an other large agglutinated foraminifera, to be carnivorous. Relatively smaller benthic foraminifera such as Elphidium and Pyrgo also have been observed capturing prey, but not feeding on them (Jepps, 1942; Suhr and others, 2008). Really small studies suggest predation by small benthic foraminifera (Christiansen, 1971; Hallock and Talge, 1994; Cehdagen, 1994).

The purpose of this study is to examine and document the trophic interactions between the smaller benthic foraminifera Ammonia tepida and several kinds of metazoans in laboratory-controlled experiments. Ammonia tepida is known as a deposit-feeder on algae (Lee, 1980; Stouff and others, 1999; Moodley and others, 2000) and bacteria (Goldstein and Corliss, 1994; Langezaal and others, 2005; Pascal and others, 2008a). Species of Ammonia have been used in numerous laboratory experiments because the genus is ubiquitous in inner-shelf, estuarine, and saltmarsh environments (Murray, 1991), where they tolerate wide ranges in temperature, salinity, and other physico-chemical parameters (e.g.. Bradshaw, 1961; Schnitker, 1974; Walton and Sloan, 1990; Debenay and others, 1998). Being hardy and readily collected, Ammonia is ideal subjects for laboratory study of living specimens.

\section{METHODS}

\section{COLLECTION OF FORAMINIFERS AND METAZOANS}

Foraminifera and invertebrates were sampled by scratching the superficial centimetre of sediment at low tide from the upper-intertidal zone of Brouage mudflat, located on the French Atlantic coast about $20 \mathrm{~km}$ south of La Rochelle, $45^{\circ} 54^{\prime} \mathrm{N}, 1^{\circ} 7^{\prime} \mathrm{W}$ (Fig. 1). Time between collection and 
experiment was minimized. This environment supports a high density of living foraminifera, especially Ammonia tepida (Pascal and others, 2008b). The meiofaunal community of this mudflat is dominated by nematodes (95\%), with subsidiary copepods (2\%), both of which are present throughout the year (Rzeznik-Orignac and others, 2003). The deposit-feeding gastropod Hydrobia ulvae (Pennant), known as the common mudsnail (90\% of macrofauna in terms of abundance), is also a common inhabitant of intertidal mudflats in Western Europe (Bachelet and Yacine-Kassab, 1987; Barnes, 1990; Sola, 1996; Bocher and others, 2007).

\section{Fig 1 here}

\section{LABORATORY PROCEDURES}

Sediment samples were washed through a $50-\mu \mathrm{m}$ sieve and the $>50-\mu \mathrm{m}$ fraction was distributed among several glass Petri dishes. Extraction of living calcareous Ammonia tepida was facilitated by exposing the sediment to 80 adult Hydrobia ulvae, common adult mudsnail (Haubois and others 2004), as previously demonstrated by Rossignol and others (2007). After two days, most of the sediment had been ingested by the gastropods and excreted as fecal pellets, and the living benthic foraminifera that had eluded the gastropod were clean and readily visible for efficient picking with a very fine brush. Specimens of A. tepida were transferred to Petri dishes filled with $0.2 \mu \mathrm{m}$ of filtered seawater from the study area. Foraminifera were acclimated for a minimum of 24 hours at $18^{\circ} \mathrm{C}$ with a daily light-dark cycle before the feeding experiment commenced.

Living nematodes were concentrated by first seawater-washing sediment samples through a $65-\mu \mathrm{m}$ nylon. Sediments $>65 \mu \mathrm{m}$ were distributed on a $0.5-\mathrm{cm}$-thick layer of coarse sand (grain size: $1 \mathrm{~mm}$ ) over a $20-\mu \mathrm{m}$ nylon mesh placed above a seawater bath and exposed to light for two days. Following this negative phototropism method described by Rzeznik-Orignac and others (2004), living nematodes migrated from the sand, through the nylon mesh, and into the seawater. The living nematodes were then cleaned of organic matter. Nematodes were transferred to $0.2-\mu \mathrm{m}$-filtered seawater from the study area and acclimated prior to the feeding experiment, as described above for $A$. tepida. 
Ten live A. tepida and 10 live nematodes or copepods were placed in $0.2-\mu \mathrm{m}$ filtered seawater on the same 5-cm-diameter Petri dish. The control dish similarly received 10 live nematodes or copepods but no foraminifera. Foraminiferal vitality was verified by observing pseudopodial activity, while nematode and copepod vitality was verified in their mobility. All feeding experiments were carried out at room temperature $\left(18^{\circ} \mathrm{C}\right)$. Nematodes were kept in the dark, whereas copepods had a 24 hours light-dark cycle. Each part of the experiment was repeated three to five times. The behaviors of foraminifera, nematodes, and copepods were observed under a stereomicroscope regularly over 24 hours. Photographs were taken with a LEICA stereomicroscope (DMIRB $\times 400$ maximum magnifications) equipped with an Olympus DP-70 digital camera and Visilog software.

An additional series of experiments was carried out where each dish had one juvenile Hydrobia ulvae gastropod and five A. tepida, under the same light-dark cycle that was applied in the copepod experiments. Observations were made with an Olympus SZX-12 stereomicroscope equipped with a Olympus E-330 numerical camera.

\section{SPECIMEN PREPARATION FOR ELECTRONIC MICROSCOPY}

The various steps of this preparation method were performed with small microcentrifuge (Eppendorf-type) tubes that were conducive to the preservation of the fine, fragile pseudopodia. When nematodes were captured by foraminifera, samples were fixed in a solution of $2.5 \%$ glutaraldehyde diluted in $0.45-\mu \mathrm{m}$ filtered seawater for 24 hours. To avoid desiccation and consequent loss of detail, the foraminiferal specimens with prey were washed with $0.2 \mathrm{M}$ cocadylate buffer ( $\mathrm{pH}$ 7.4). Postfixation was accomplished using $2 \% \mathrm{OsO}_{4}$ diluted in the cocadylate buffer, followed by three rinses with $0.45-\mu \mathrm{m}$-filtered seawater and dehydration in a $50-75-95 \%$ series of ethanol baths, plus two baths of $100 \%$ ethanol. Specimens were then immersed in HMDS (hexamethyldisilazane) for 10 minutes, after which they air-dried. Dried specimens were mounted on SEM stubs covered with carbon-conductive adhesive tape and double-coated with carbon. Observations and imaging were obtained with a Jeol 6301F SEM at the SCIAM (Service Commun d'Imagerie et d'Analyses Microscopiques) of the University of Angers. 


\section{RESULTS \\ PREDATOR-PREY RELATIONSHIP BETWEEN FORAMINIFERA AND NEMATODES}

Acclimated specimens of Ammonia tepida extruded a dense network of pseudopodia that extended onto the dorsal and ventral surfaces of the test. The foraminifera generally oriented themselves perpendicular-to-oblique relative to the bottom of the Petri dish, and used their pseudopodial network to attach at two main points on the glass bottom (Fig. 2a).

Nematodes encountering the networks were immediately entrapped (Fig. 2b, observation using a camera and stereomicroscope), adhering to the pseudopodia or to the cyst on the ventral side of the tests (Figs. 2f-i). When stuck in the foraminiferal pseudopodia, the nematodes struggled, but rarely escaped. Some nematodes were captured by two foraminifera (Figs. 2f, 2g). About 18 hours after initial contact, the foraminifera began to empty the nematode of its soft tissues (Fig. 2e). All of the prey's contents suck out within six hours (Figs. 2c, 2d), leaving only an empty cuticula (Fig. 2c, 2d). Each cast-off cuticula was characterized by a hole that had been created by the predatory foraminifera (Figs. 2d). The predation of nematodes by A. tepida was observed every time these two meiofaunal organisms made contact. The control nematodes that were not in placed into association with foraminifera remained alive and unscathed after 24 hours.

Fig. 2 here

PREDATOR-PREY RELATIONSHIP BETWEEN FORAMINIFERA AND OTHER METAZOAN ORGANISMS

As with the nematodes, copepods also fell prey to A. tepida whenever the two made contact. Despite vigorous attempts to escape, copepods could not free themselves from the pseudopodial mesh. Often, two foraminifera trapped the same copepod (Fig. 3a). After ingesting the soft tissues of the prey, the empty carapace was discarded. The predation of these copepods by A. tepida was observed each time these two organisms were put together. 
One observation was made of A. tepida feeding on a juvenile gastropod. The foraminifera attached to the aperture of a living Hydrobia and, about 20 hours later, the snail shell was empty (Fig. $3 b, 3 c)$.

\section{DISCUSSION}

The carnivorous behavior of Ammonia tepida in the laboratory has also been observed on meio-macrofauna. It appears that this carnivorous behaviour of A. tepida is not specific for the specimens of our study area. A similar carnivorous behaviour has been observed in A. tepida collected from the Japanese coast (H. Nomaki, personal communication, 2008) indicating that carnivory in $A$. tepida is a general feeding strategy under laboratory conditions. But is this feeding strategy used by A. tepida in its natural environment?

In mudflat environments, due to the abundance of nematodes (on average, 42 times more abundant than foraminifera) and foraminifera, especially in the surface sediments of mudflats (Pascal and others, 2008b), contact between A. tepida and small metazoans is likely to occur very frequently. In the Brouage mudflat, for example, nematode abundances range $800-4,050 \times 10^{3} \mathrm{~m}^{-2}$ (mean of $2,100 \times 10^{3} \mathrm{~m}^{-2}$ ) with maximum abundances in winter and spring (Rzeznik-Orignac and others, 2003), while foraminifera range $20-170 \times 10^{3} \mathrm{~m}^{-2}$ (mean of $50 \times 10^{3}$ foraminifera $\mathrm{m}^{-2}$ ) with their maximum in winter (Pascal and others, 2008b). By preying on meiofauna, A. tepida may be considered to be on a trophic level similar to metazoan consumers, but it is probably not alone among the benthic foraminifera. Microscope imaging with fatty-acid biomarker analysis strongly suggests that the diet of Astrammina rara (Rhumbler) includes polychaetes, crustaceans, molluscs, and echinoderms (Suhr and others, 2008).

Chandler (1989) reported on Ammonia beccarii (Linné) thought to possibly be in an amensal relationship with the copepod Amphiascoides limicola (Brady). The presumption is that this is an indirect result of having consumed most of microflora, leaving the less nutritious detritus for the copepod. We suggest that the lower copepod densities observed by Chandler (1989) could also be due 
to foraminiferal predation or copepod avoidance of sediments supporting high densities of Ammonia. However, our results suggest that A. tepida are able to directly feed on large and actively moving grazers.

Ammonia species have typically been considered herbivores, with Ammonia tepida feeding upon algae and bacteria (Goldstein and Corliss, 1994; Moodley and others, 2000; Langezaal and others, 2005; Pascal and others, 2008a). Moodley and others (2000) reported Ammonia sp. exhibiting rapid uptake of freshly deposited algal carbon. It is now evident that some of those foraminifera are likely to be omnivorous. Ammonia, the most common benthic foraminiferal genus, ubiquitous in inner shelf, estuarine, and saltmarsh environments, may be able to employ various feeding strategies according to the most available food sources. Thus, A. tepida's position in the benthic food web is complex, occupying both primary and secondary consumer positions. Thus, they may have a greater impact on benthic community structure than previously suspected. Because of their limited motility, active hunting for prey is probably not common among carnivorous foraminifera. Whereas A. tepida spreads its pseudopodial network more extensively in this feeding mode than when grazing, the trap appears to be intentionally set to entangle larger, mobile prey that unwarily wander into it. Additional experiments are needed to confirm if A. tepida switches feeding modes according to the most available food sources.

Three significant questions arise from our results:

\section{How do prey remain attached to foraminiferal pseudopodia?}

Goldstein (1999) stated that the pseudopodia of carnivorous foraminifera are specifically designed to catch prey. Foraminifera secrete an adhesive (Buchanan and Hedley, 1960), possibly in their Golgi vesicles (Goldstein, 1999), which is then transported to the peripheral cytoplasm and released by expulsion in the vicinity of prey (Anderson and Lee, 1991; Bowser and others, 1992). This substance is very sticky and thought to be non-toxic (Langer and Bell, 1995). We observed that the pseudopodia and ventral cyst of A. tepida are capable of retaining very active nematodes and copepods. Thus, A. tepida is able to produce an adhesive substance that can be used for capturing meio-macrofauna. However, we cannot confirm that this adhesive substance is produced only for capturing food. In the case of feeding on bacterial biofilm, Bernhard and Bowser (1992), using time- 
lapse microscopy, revealing that biofilm parcels are transported extracellularly toward the foraminiferal cell body by pseudopodia, an observation which further implicates pseudopodial function in foraminiferal trophic mechanisms.

\section{How do foraminifera immobilize prey?}

It is not clear from our observations whether foraminifera sedate or kill their prey prior to ingestion. It is conceivable that foraminifera use narcotic agents or extracellular enzymes to immobilize or kill their prey, as Anderson and Bé (1976) suggested for planktonic foraminifera. In either case, the digestion of prey by foraminifera usually occurs via extruded pseudopodia (Buchanan and Hedley, 1960), and that process will eventually terminate any active resistance.

\section{Fig. 3 here}

\section{How do foraminifera penetrate the cuticula of nematodes?}

Austin and others (2005) propose that foraminifera such as Haynesina Banner and Culver use their test ornamentation to mechanically break diatom frustules. Ammonia tepida also present pustules around the aperture of the test (Fig. 3d, e) and this ornamentation may be used in penetrating cuticula. It has been suggested that secretions by pelagic foraminifera aid in digesting prey (Snider and others, 1984). Spindler and others (1984) claim that pelagic foraminiferal pseudopodia are not physically capable of boring through crustacean carapaces, and therefore there some substance must be secreted to dissolve the carapace at the point of entry. Benthic foraminifera such as A. tepida may also use chemical digestion. Bowser and others (1985) observed pseudopodial activities in Allogromia, and reported that pseudopodia tore small pieces from a gel, a behavior termed skyllocytosis. The authors suggested that skyllocytosis may also be used by carnivorous foraminifera to obtain prey tissues. Skyllocytosis is an alternative hypothesis for how A. tepida penetrates the nematode cuticula.

\section{CONCLUSIONS}

Although previous studies reported Ammonia tepida as an herbivore that feeds on algae and bacteria, the species behaved a carnivore in our laboratory experiments, intentionally orienting itself and extending its sticky pseudopodial network to capture metazoans that wandered too close. We 
observed A. tepida preying upon nematodes, copepods, and a gastropod larva that were placed near them. Thus, the species is probably omnivorous and secondary consumer in its natural environment, possibly switching feeding modes to take advantage of the food that is most readily available and finally may potentially influence the structure of benthic communities. Further experiments are needed to determine whether A. tepida has a trophic preference when multiple food types are simultaneously available. We also need to quantify in situ carbon fluxes between nematodes, copepods, juvenile Hydrobia, and this foraminifera, and then integrate these fluxes in a food web as we continue unravelling the complexities of the carbon cycle in coastal mudflats.

\section{ACKNOWLEGMENTS}

The work was supported by the Charente Maritime Regional Council and the French ANR (National Research Agency) through the VASIREMI project "Trophic significance of microbial biofilms in tidal flats“ (contract ANR-06-BLAN-0393-01). Special thanks to the technical assistance of the SIAM of the University of Angers. We are grateful to Ralf Schiebel and Frans Jorissen for their helpful comments on the manuscript. We are also grateful to Carolyn Engel-Gautier and anonymous foraminiferologist for English corrections.

\section{REFERENCES}

AltenBACH, A. V., 1992, Short term processes and patterns in the foraminiferal response to organic flux rates: Marine Micropaleontology, v. 19, p. 119-129.

ANDERSON, O. R., and BÉ, A. W. H., 1976, A cytochemical fine structure study of phagotrophy in a planktonic foraminifer Hastigerina pelagica (d'Orbigny): Biological Bulletin, v. 151, p. 437449.

, and LEE, J. J., 1991, Cytology and fine structure, in Lee, J. J., and Anderson, O. R. (eds.), Biology of Foraminifera: Academic Press, London, p. 7-40. 
Austin, H. A., Austin W. E. N., and Paterson, D. M., 2005, Extracellular cracking and content removal of the benthic diatom Pleurosigma angulatum (Quekett) by the benthic foraminifera Haynesina germanica (Ehrenberg): Marine Micropaleontology, v. 57, p. 68-73.

BACHELET, G., and YACINE-KASSAB, M., 1987, Post-recruitement phase population dynamics of the intertidal gastropod Hydrobia ulvae (Pennant): Journal of Experimental Marine Biology and Ecology, v. 111, p. 37-60.

BARNES, R. S. K., 1990, Reproductive strategies in contrasting populations of the coastal gastropod Hydrobia ulvae. II. Longevity and life-time egg production: Journal of Experimental Marine Biology and Ecology, v. 138, p. 183-200.

Bé, A. W. H., Hemleben, C., Anderson, O. R., Spindler, M., Hacunda, J., and TuntivateCHOY, S., 1977, Laboratory and field observations of living planktonic foraminifera: Micropaleontology, v. 23, p. 155-179.

Bernhard, J. M., and BowSER, S. S., 1992, Bacterial biofilms as a trophic resource for certain benthic foraminifera: Marine Ecology Progress Series, v. 83, p. 263-272.

Bocher, P., Piersma, T., Dekinga, A., KraAn, C., Yates, M. G., Guyot, T., Folmer, E. O., and RADENAC, G., 2007, Site- and species-specific distribution patterns of molluscs at five intertidal soft-sediment areas in northwest Europe during a single winter: Marine Biology, v. 151, p. 577594.

Boltovskoy, E., and Wright R., 1976, Recent Foraminifera: W. Junk, The Hague, The Netherlands, $515 \mathrm{p}$.

Bowser, S. S., DelaCA, T. E., and RIEDER, C. L., 1986, Novel extracellular matrix and microtubule cables associated with pseudopodia of Astrammina rara, a carnivorous Antarctic foraminifer: Journal of Ultrastructure Molecular Structure Reseach, v. 94, p. 149-160.

-, Alexander, S. P., Stockon, W. L., and Delaca, T. E., 1992, Extracellular matrix augments mechanical properties of pseudopodia in the carnivorous foraminiferan Astrammina rara: role in prey capture: Journal of Protozoology, v. 39, p. 724-732. 
-, McGee-Russell, S. M., RIEDER, C. L., 1985, Digestion of prey in foraminifera is not anomalous: A correlation of light microscopic, cytochemical, and HVEM technics to study phagotrophy in two allogromiids: Tissue Cell, v. 17, p. 823-839.

BRADSHAW, J. S., 1961, Laboratory experiment on the ecology of foraminifera: Contributions from the Cushman Foundation for Foraminiferal Research, v. 12, p. 87-106.

Buchanan, J. B., and Hedley, R. D., 1960, A contribution to the biology of Astrorhiza limicola: Journal of Marine Biology Association U. K., v. 39, p. 549-560.

BUZAS, M. A., 1982, Regulation of the foraminiferal density by predation in the Indian River, Florida: Journal of Foraminiferal Research, v. 12, p. 66-71.

CARON, D. A., and BÉ, A. W. H., 1984, Predicted and observed feeding rates of the spinose planktonic foraminifer Globigerinoides sacculifer: Bulletin of Marine Science, v. 38, p. 1-10.

Cedhagen, T., 1988, Position in the sediment and feeding biology in Astorhiza limicola Sandahl, 1857 (Foraminiferidae, Astrorhizidae): Sarsia, v. 73, p. 43-47.

— 1994, Taxonomy and biology of Hyrrokkin sarcophaga gen. and sp. n., a parasitic foraminiferan (Rosalinidae): Sarsia, v. 79, p. 65-82.

Chandler, G. T., 1989, Foraminifera may structure meiobenthic communities: Oecologia, v. 81, p. $354-360$

Christiansen, O., 1971, Notes of the biology of foraminifera: Vie et Milieu, $3^{\text {rd }}$ Symposium Européen de Biologie Marine, Suppl., v. 22, p. 465-478.

Debenay, J.-P., Eichler, B. B., Duleba, W., Bonetti, C., and Eichler, P. P., 1998, Sensitivity of foraminifers to stratification of water masses in shallow coastal lagoons: Marine Micropaleontology, v. 35, p. 67-89.

DelACA, T. E., 1986, The morphology and ecology of Astrammina rara: Journal of Foraminiferal Research, v. 16, p. 216-224.

, KARL, D. M., and LIPPS, J. H., 1981, Direct use of dissolved organic carbon by agglutinated benthic foraminifera: Nature, v. 289, p. 287-289. 
ElLISON, R. L., 1984, Foraminifera and meiofauna on an intertidal mudflat, Cornwall, England: populations; respiration and secondary production; and energy budget: Hydrobiologia, v. 109, p. $131-148$.

Fontanier, C., Jorissen, F. J., Licari, L., AleXandre, A., Anschutz, P., and Carbonel, P., 2002, Live benthic foraminiferal faunas from the Bay of Biscay: faunal density, composition and microhabitats: Deep Sea Research, v. 49, p. 751-785.

GoldSTEIN, S. T., 1999, Foraminifera: a biological overview, in Sen Gupta, B. K. (ed.), Modern Foraminifera. Kluwer Academic Publishers, Norwell, Massachusetts, p 37-55.

, and CoRLISS, B. H., 1994, Deposit feeding in selected deep-sea and shallow-water benthic foraminifera: Deep Sea Research, v. 41, p. 229-441.

HALlOCK, P., and TAlge, H. K., 1994, A predatory foraminifer, Floresina amphiphaga, n. sp., from the Florida Keys. Journal of Foraminiferal Research, v. 24, p. 210-213.

Haubois, A. G., Guarini, J. M., Richard, P., Hemon, A., Arotcharen, E., and Blanchard, G. F., 2004, Differences in spatial structures between juveniles and adults of the gastrop Hydrobia ulvae on an intertidal mudflat (Marennes-Oléron Bay, France) potentially affect estimates of local demographic processes: Journal of Sea Research, v. 51, p. 63-68.

Heinz, P., Sommer, S., PfannKuche, O., and Hemleben, C., 2005, Living benthic foraminifera in sediments influenced by gas hydrates at the Cascadia convergent margin, NE Pacific: Marine Ecology Progress Series, v. 304, p. 77-89.

Hemleben, C., Spindler, M., and Anderson, O. R., 1988, Modern Planktonic Foraminifera: Springer-Verlag Verlag, New York, 327 p.

JEEPS, M. W., 1942, Studies on Polystomella Lamarck (Foraminifera). Journal of the Marine Biological Association of the United Kingdom, v. 25, p. 607-666.

JONES, R. K., and CHARNOCK, M. A., 1985, "Morphogroups" of agglutinating foraminifera. Their life positions and feeding habitats and potential applicability in (paleo)ecological studies: Revue de Paléobiologie, v. 4, p. 311-320.

LANGer M. R, LiPPS J. H., and Guillermo, M. 1995, Predation on foraminifera by the dentaliid deep-sea scaphopod Fissidentalium megathyris: Deep-Sea-Research, v. 6, p. 849-857 
Langezaal, A. M., Jannink, N. T., Pierson, E. S., and van der ZwaAn, G. H., 2005, Foraminiferal selectivity towards bacteria: an experimental approach using cell-permeant stain: Journal of Sea Research, v. 54, p. 256-275.

LEE, J. J., 1980, Nutrition and physiology of the foraminifera, in Levandowsky, M., and Hutner, S. H. (eds.), Biochemistry and Physiology of Protozoa, v. 3, Academic Press, London, p. 43-66.

, and ANDERson, O. R., 1991, Symbiosis in foraminifera, in Lee, J. J., and Anderson, O. R. (eds.), Biology of Foraminifera: Academic Press, London, p. 157-220.

-, SAng, K., Ter Kuile, B., Strauss, E., LeE, P. J., and FABER, W. W., 1991, Nutritional and related experiments on laboratory maintenance of three species of symbiont-bearing, large foraminifera: Marine Biology, v. 109, p. 417-425.

Linke, P., Alterbach, A. V., Graf, G., and Heeger, T., 1995, Responses of deep-sea benthic foraminifera to a simulated sedimentation event: Journal of Foraminiferal Research, v. 25, p. $75-82$.

LIPPS, J. H., 1983, Biotic interactions in benthic foraminifera, in Tevesz, M. J. S., and Mc Call, P. L. (ed.), Biotic interactions in recent and fossil benthic communities, Plenum Press, New York, p. $331-373$.

LUTZE, G.F., and AltENBACH, A., 1988, Rupertina stabilis (Wallich), a highly adapted suspensionfeeding foraminifer. Meyniana, v. 40, p. 55-69.

-, and THIEL, H., 1989, Epibenthic foraminifera from elevated microhabitats: Cibicidoides wullerstorfi and Planulina ariminensis. Journal of Foraminiferal Research, v. 19 p. 153-158.

Moodley, L., HeIP, C. H. R., and MiddelburG, J. J., 1998, Benthic activity in sediments of the northwestern Adriatic Sea: sediment oxygen consumption, macro- and meiofauna dynamics: Journal of Sea Research, v. 40, p. 263-280.

-, Boshker, H. T. S., Middelburg, J. J., Pel, R., Herman, P., De Deckere, E., and Heip, C. H. R., 2000, Ecological significance of benthic foraminifera: ${ }^{13} \mathrm{C}$ labelling experiments: Marine Ecology Progress Series, v. 202, p. 289-295. 
-, Middelburg, J. J., Boshker, H. T. S., Duineveld, R., Pel, R., Herman, P. M. J., and

HEIP, C. H. R., 2002, Bacteria and foraminifera: key players in a short-term deep sea benthic response to phytodetritus: Marine Ecology Progress Series, v. 236, p. 23-29.

, — - Soetaert, K., Boshker, H. T. S., Herman, P. M. J., and Heip, C. H. R., 2005, Similar rapid response to phytodetritus deposition in shallow and deep-sea sediments: Journal of Marine Research, v. 63, p. 457-469

MURRAY, J. W, 1963, Ecological experiments on Foraminiferida: Journal of the Marine Biological Association of the United Kingdom, v. 43, p. 621-642.

— 1991, Ecology and Paleoecology of Benthic Foraminifera, Longman, New-York, 397 p.

— , and ALVE, E., 2000, Major aspects of foraminiferal variability (standing crop and biomass) on a monthly scale in an intertidal zone: Journal of Foraminiferal Research, v. 30, p. 177-191.

Nomaki, H., Ogawa, N.O., Ohkouchi, N., Suga, H., Toyofuku, T., Shimanaga, M., NaKatsuka, T., and KitaZAto, H., 2008, Benthic foraminifera as trophic links between phytodetritus and benthic metazoans: carbon and nitrogen isotopic evidence: Marine Ecology Progress Series, v. 357, p. 153-164.

NYHOLM, K. G., 1956, Studies on Recent Allogromiidae, I. Micrometula hyalostriata n. gen., n. sp., from Gullmar Fjord, Sweden. Zoologiska Bidrrag från Uppsala,v. 31, p. 483-495.

PASCAl, P. Y., DuPUY, C., RichaRd, P., NiQuil, N., 2008a, Bacterivory in the common foraminifer Ammonia tepida: isotope tracer experiment and the controlling factors: Journal of Experimental Marine Biology and Ecology, v. 359, p. 55-61.

-, Dupuy, C., Richard, P., Mallet, C., ARmynot du Chatelet, E., and Niquil, N., 2008b, Seasonal variation in consumption of benthic bacteria by meio and macrofauna in an intertidal mudflat: Limnology and Oceanography, v. 54, p. 1048-1059.

Rossignol, L., Dupuy, C., Pascal, P. Y., and Debenay, J.-P., 2007, Hydrobia ulvae: a deposit feeder for cleaning living hard-shelled foraminifera: Journal of Foraminiferal Research, v. 37, p. $8-11$. 
RZEZnik-OrignaC, J., FICHET, D., and Boucher, G., 2004a, Spatio-temporal structure of the nematode assemblages of the Brouage mudflat (Marennes Oléron, France): Estuarine, Coastal and Shelf Science, v 58, p. 77-88.

$\longrightarrow,-$, and $\longrightarrow, 2004 \mathrm{~b}$, Extracting massive numbers of nematodes from muddy marine deposits: efficiency and selectivity: Nematology, v. 6, p. 604-616.

SCHNITKER D, 1974, Ecotype variation in Ammonia beccarii (Linné): Journal of Foraminiferal Research, v. 4, p. 216-223.

SLITER W. V., 1965, Laboratory experiments on the life cycle and ecologic controls of Rosalina globularis d'Orbigny: Journal of Paleontology, v. 12, p. 210-215.

SNider, L. J., BurnetT, B. R., and HesSLER, R. R., 1984, The composition and distribution of meiofauna and nanobiota in a central North Pacific deep-sea area: Deep Sea Research, v. 31, p. $1225-1249$.

SolA, J. C., 1996, Reproduction, population dynamics, growth and production of Scrobicularia plana da Costa (Pelecypoda) in the Bidasoa estuary, Spain: Aquatic Ecology, v. 30, p. 283-296.

Spindler, M., Hemleben, C., Salomons, J. B., and Smit, L. P. (1984). Feeding behavior of some planktonic foraminifers in laboratory cultures: Journal of Foraminiferal Research, v. 14, p. $237-$ 249.

Stouff, V., Geslin, E., Debenay, J.-P., and Lesourd, M., 1999, Origin of morphological abnormalities in Ammonia (Foraminifera): Studies in laboratory and natural environments: Journal of Foraminiferal Research, v. 29, p. 152-170.

Suhr S. B., Alexander, S. P., Gooday, A. J., David W., Pond D. W., and Bowser, S. S., 2008, Trophic modes of large Antarctic foraminifera: roles of carnivory, omnivory, and detritivory: Marine Ecology Progress Series, v. 371, p. 155-164.

WAlton, W. R., and SloAN, B. J., 1990, The genus Ammonia Brünnich, 1772: its geographic distribution and morphologic variability: Journal of Foraminiferal Research, v. 20, p. 128156. 
Witte, U., Wenzhofer, F., Sommer, S., Boetius, A., Heinz, P., Abarie, N., SAnd, M., Cremer, A., Abraham, W. R., Jorgensen, B. B., and Pfannkuche, O., 2003, In situ experimental evidence of the fate of a phytodetritus pulse at the abyssal sea floor. Nature, v. 24, p. 763-766 


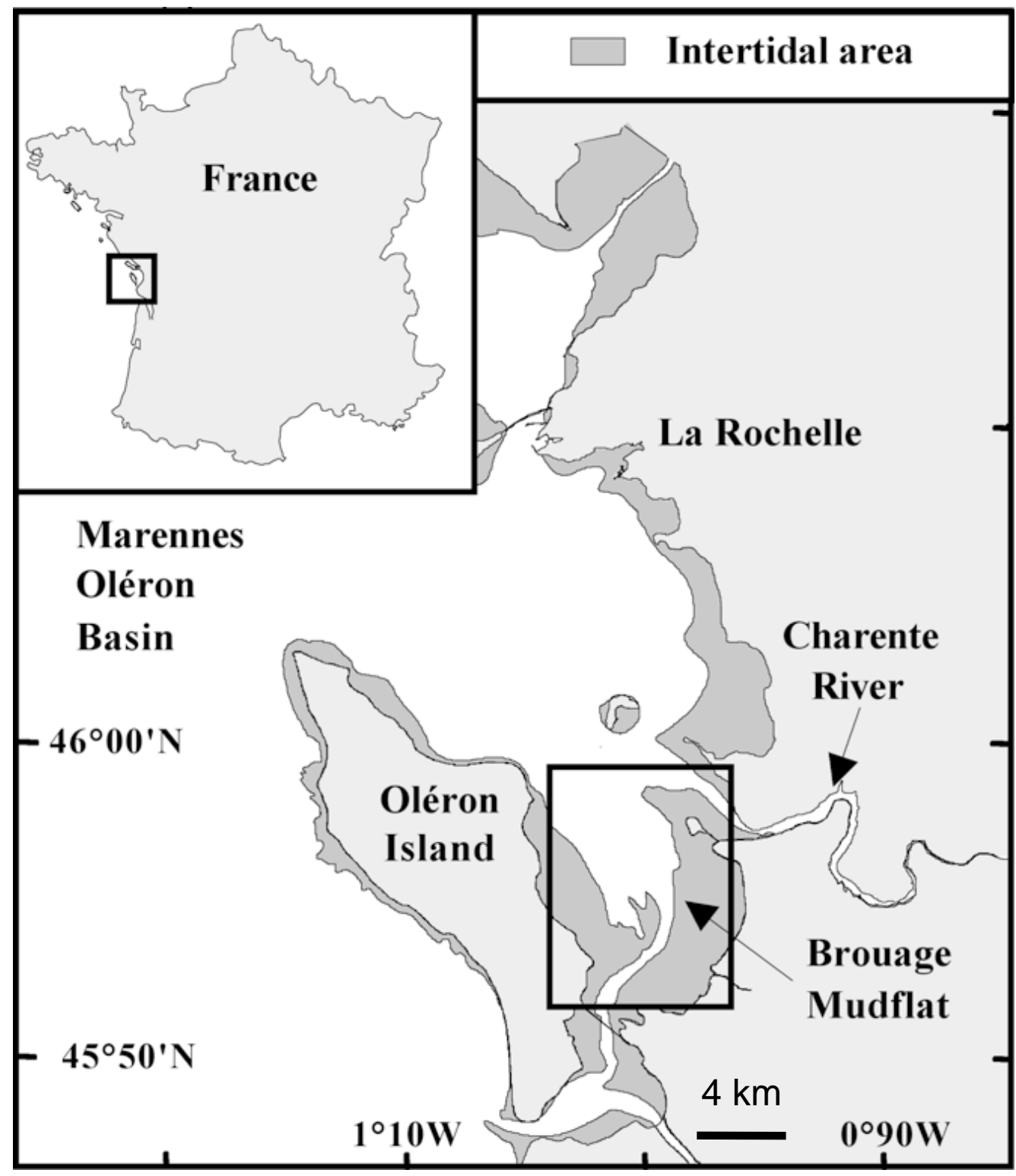

FIGURE 1: Location of the sampling site at Brouage mudflat. Extremity of the arrow: sampling station. 


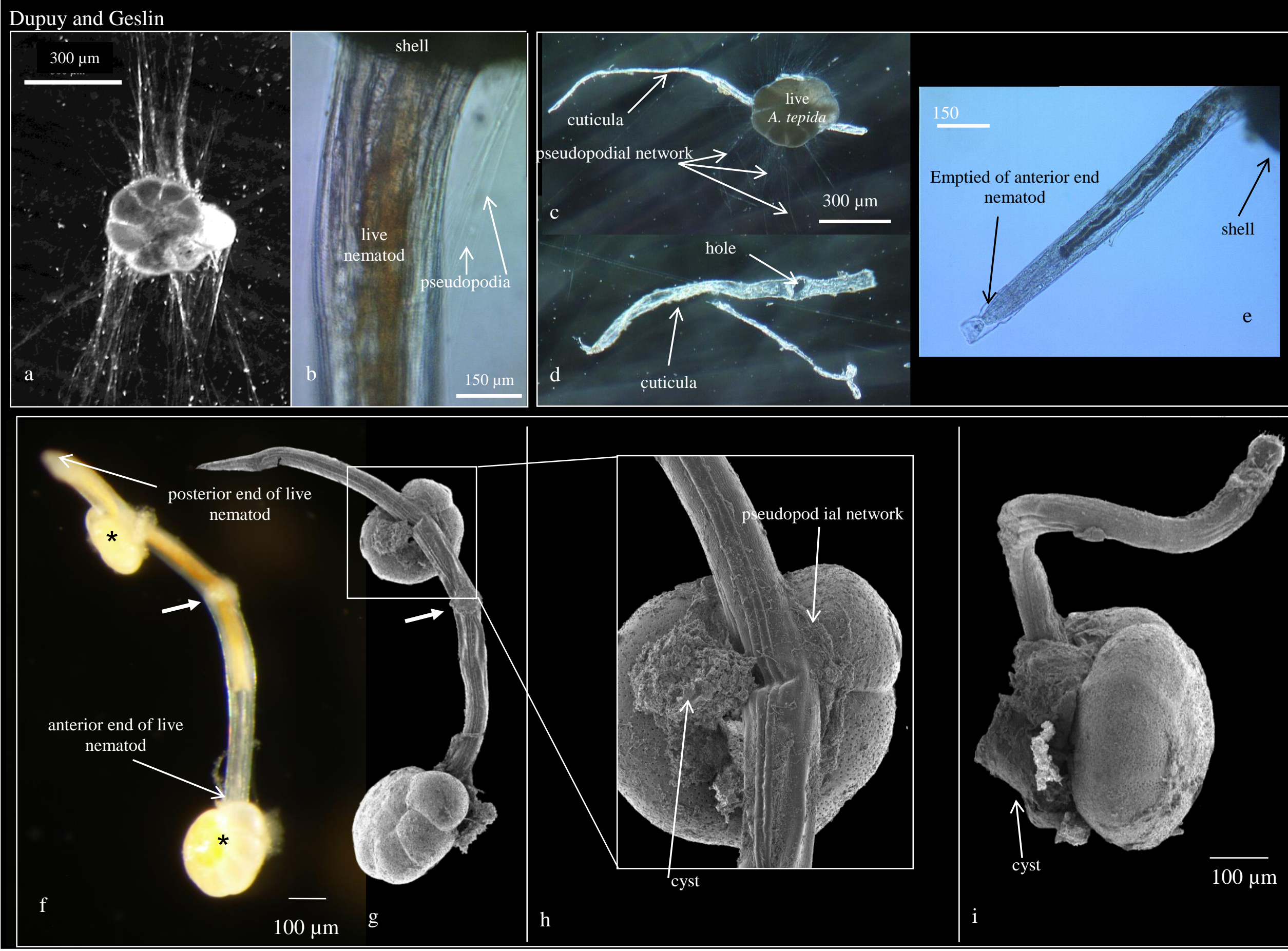


FiguRE 2: Ammonia tepida predation on nematodes (a-f, photomicroscopic images; g-i: scanning electron micrographs). a Pseudopodial network of foraminiferan; b Nematode caught alive; note pseudopodia visible between specimens; c Pseudopodial network ingesting nematode; only an empty cuticula remains after 18 hours; d Once the nematode was ingested, the foraminiferan discards the empty cuticula that now bears a hole; e Prior to the 18-hour experiment, the foraminiferan begins to empty the nematode of its contents; $\mathbf{f}, \mathbf{g}$ Two foraminifera (stars) ingesting a nematode; arrow points to injury possibly from a previous encounter with a foraminiferan; $\mathbf{h}$ Detail of image $\mathrm{g}$; $\mathbf{i}$ Captured nematode; arrow points to cyst formed on umbilical side of the foraminiferan; also note pseudopodia lack remnants of the recent meal. 

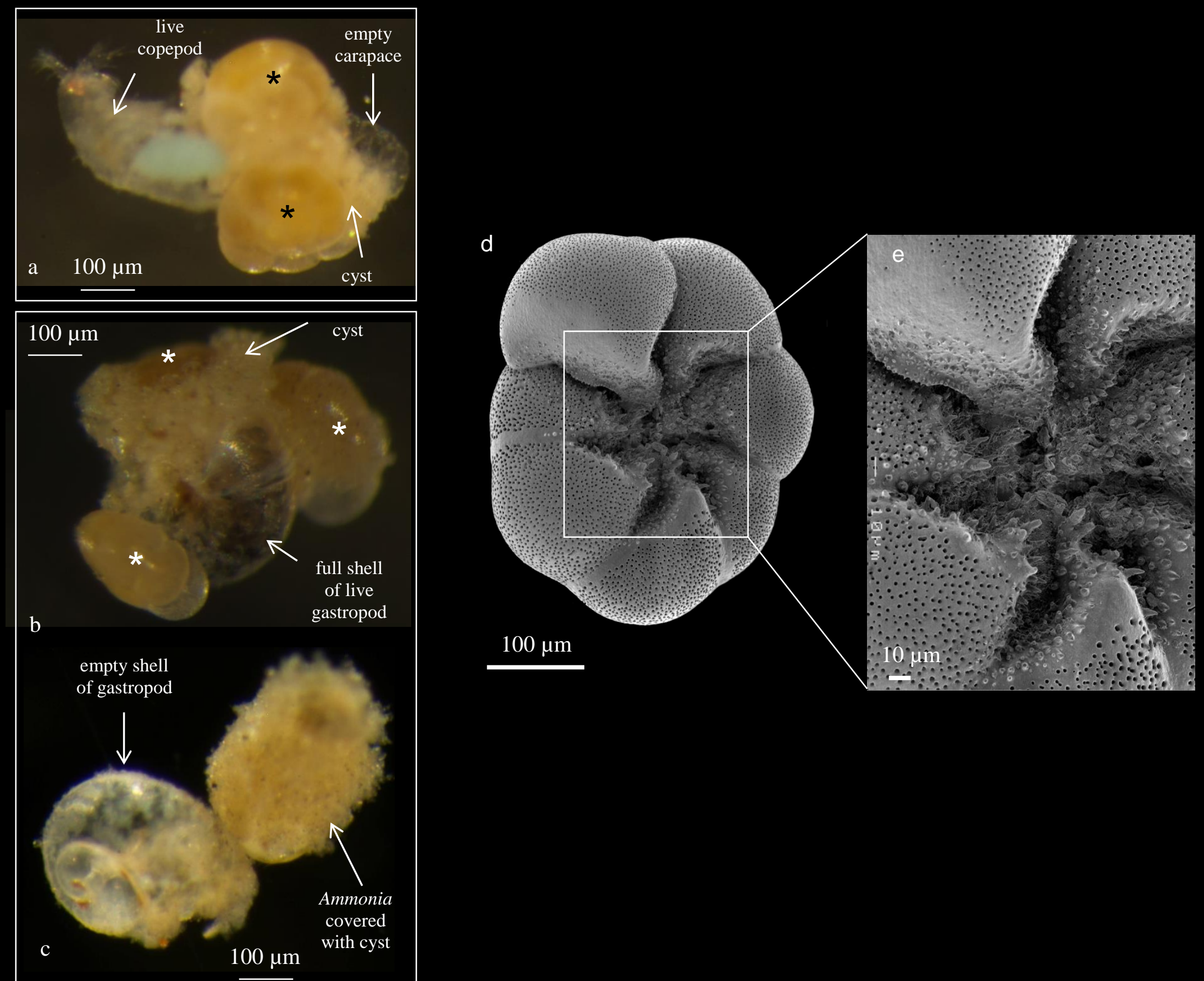
FIGURE 3: Ammonia tepida predation on copepods and gastropod larvae (a-c: photomicroscopic images; d: electron micrograph) a Two foraminifera (denoted

by stars) feeding on a copepod; note the part of the carapace visible on the right is now empty; b Benthic juvenile gastropod Hydrobia ulvae caught alive by three foraminiferans (denoted by stars); c After 20 hours, the gastropod shell is empty; note the cyst-covered foraminiferan; d Oblique umbilical view of $A$. tepida; e detailed view of imaged. 